\title{
Sistem Informasi Monitoring Data Persatuan Guru Republik Indonesia Kecamatan Bengkalis Menggunakan Metode Extreme Programming dan Framework Codeigniter
}

\author{
Mansur $^{1}$, Mega Daryuni \\ ${ }^{1}$ Program Studi DIV-Keamanan Sistem Informasi Politeknik Negeri Bengkalis \\ ${ }^{2}$ Program Studi DIII-Teknik Informatika Politeknik Negeri Bengkalis \\ 1,2 Jalan Bathin Alam, Sungai Alam, Bengkalis, Riau , telp. (+62766) 8001000 \\ email: ${ }^{1}$ mansur@polbeng.ac.id, ${ }^{2}$ mega.daryuni@gmail.com
}

\begin{abstract}
Abstrak
Persatuan Guru Republik Indonesia (PGRI) merupakan sebuah organisasi perjuangan, profesi dan ketenagakerjaan bersekala nasional yang anggotanya terdiri dari para Guru dan Tenaga kependidikan. Data anggota PGRI belum terpusat dan masih dilakukan dengan cara yang manual, pada iuran PGRI juga mengalami permasalahan yang kompleks dan sering dihadapi, yaitu terdapat perbedaan antara jumlah anggota PGRI setiap sekolah dengan jumlah iuran yang telah disetor. Desain sistem ini dirancang menggunakan metode Extreme Programming $(X P)$ dan Framework Codeigniter(CI) yang dapat menghasilkan informasi yang berhubungan dengan PGRI dan Sekolah kecamatan Bengkalis, seperti mengetahui jumlah dan identitas Sekolah, jumlah dan identitas anggota PGRI, siapa saja anggota PGRI yang belum terdaftar sebagai anggota resmi PGRI, serta monitoring pembayaran iuran PGRI. Adapun fitur yang ada pada sistem ini yaitu Approval registrasi anggota pgri, input data Sekolah dan anggota PGRI, upload struk pembayaran, filter iuran, dan export data Sekolah dan anggota PGRI.
\end{abstract}

Kata Kunci-Sistem Informasi, Monitoring, Data PGRI, Metode XP, Framework CI

\begin{abstract}
The Association of Teachers of the Republic of Indonesia (PGRI) is a national scale struggle, profession and employment organization whose members consist of teachers and education personnel. PGRI member data is not centralized and is still being done manually. In the matter of PGRI dues, there are also complex and often faced problems, between the number of PGRI members in each school and the total contributions that have been paid. This system design is designed using the Extreme Programming (XP) method and the Codeigniter Framework (CI) which can produce information related to PGRI and Schools in Bengkalis subdistrict, such as knowing the number and identity of schools, the number and identity of PGRI members, who are PGRI members who have not been registered. as an official member of PGRI, as well as monitoring the payment of PGRI dues. The features that exist in this system are the registration approval for pgri members, data input of schools and PGRI members, uploading payment receipts, filtering dues, and exporting school data and PGRI members.
\end{abstract}

Keywords - Information Systems, Monitoring, PGRI Data, the XP Method, Framework CI

\section{Pendahuluan}

PGRI merupakan sebuah organisasi perjuangan, profesi dan ketenagakerjaan bersekala nasional yang beranggotakan Guru dan Tenaga kependidikan[1]. Sebagai organisasi pelopor dan pejuang, PGRI mempunyai peran penting yang diberikan amanahkan oleh pemerintah dalam memperjuangkan banyak hal dalam bidang pendidikan terutama untuk mencerdaskan kehidupan bangsa dan meningkatkan kualitas pendidikan bangsa Indonesia. Salah satu tugas dan fungsinya yaitu melakukan monitoring data sekolah dan identitas anggota PGRI[2]. Monitoring data PGRI meliputi jumlah identitas anggota, mengetahui siapa saja guru dan tenaga kependidikan yang 
belum terdaftar sebagai anggota resmi, melakukan monitoring terhadap jumlah sekolah dan identitas sekolah, dan melakukan monitoring pembayaran iuran PGRI. Monitoring data PGRI perlu dilakukan dengan dukungan sebuah sistem informasi berbasis komputer yang mumpuni, sehingga kondisi aktual per waktu dapat diketahui secara realtime[3].

Beberapa penelitian menyatakan bahwa monitoring penting untuk dilakukan, karena monitoring merupakan suatu proses pemantauan program atau kegiatan, sebagai kesadaran sikap dan perilaku serta tugas yang ingin diketahui agar dapat mengukur suatu program berdasarkan pergerakan waktu yang dimana menunjukkan perubahan ke arah yang jelas dan bermanfaat[15]. Melalui monitoring pengurus PGRI bisa melakukan pengumpulan data dan analisis informasi (berdasarkan indikator yang sudah diterapkan) mengenai program atau kegiatan PGRI, sehingga dapat dilakukan perbaikan untuk penyempurnaan program PGRI selanjutnya[16]. Selain itu, pembahasan tentang sistem informasi data guru juga pernah dilakukan pada dinas pendidikan kota lubuklinggau menggunakan model UML dengan permasalahan tentang bagaimana melakukan proses pencarian, menyeleksi, dan menemukan guru atau tenaga pendidik menggunakan filter berdasarkan berdasarkan kecamatan, sekolah, jenjang pendidikan, pangkat, status, tingkat pendidikan, jenis kelamin dan golongan guru[14].

Selanjutnya untuk melakukan monitoring sangat membutuhkan sistem informasi dalam membantu proses pendataan secara realtime yang dapat diakses dari mana saja dan kapan saja, tanpa harus tergantung kepada komputer lokal[4]. Dalam mendesain sebuah sistem informasi dengan baik memerlukan metode SDLC (System Development Life Cycle) supaya hasil yang diharapkan sesuai dengan kebutuhan pengguna[5]. Selain metode SDLC, metode ExtremeProgramming (XP) merupakan salah satu teknik yang cepat dan mampu bekerja dengan baik sesuai dengan kebutuhan pengguna sehingga dalam melakukan pengembangan sistem benar-benar dimulai dengan membangun komponen yang paling sederhana terlebih dahulu[6]. Metode Extreme programming juga mampu membuat sebuah aplikasi dengan mudah, karena dapat diterapkan pada berbagai permasalahan yang ada[7]. Untuk mengembangkan sistem berbasis website agar lebih cepat, tersusun dan terstruktur maka perlu sebuah Framework Codeigniter (CI) yang merupakan framework untuk sistem berbasis web yang dibuat dalam format PHP dengan model MVC (Model, View, Controller) dan open source[8]. Dengan adanya model MVC, struktur kode yang dihasilkan menjadi lebih terstruktur dan memiliki standar yang jelas[9].

PGRI Kecamatan Bengkalis salah satu organisasi guru yang mengelola anggota PGRI kecamatan, bertugas melakukan pendataan anggota PGRI dan sekolah yang ada di Kecamatan Bengkalis. Data anggota PGRI belum terpusat dan masih dilakukan secara manual seperti diinput satu persatu oleh operator sekolah kedalam microsoft excell, dan data tersebut diberikan kepada pengurus PGRI dalam bentuk printout, terkait iuran PGRI juga mengalami permasalahan yang kompleks dan sering dihadapi, antara jumlah anggota PGRI setiap sekolah dengan jumlah iuran yang telah disetor, namun terkadang ada beberapa sekolah yang tidak membayar iuran penuh atau sesuai dengan jumlah anggota PGRI yang ada di sekolahnya, sehingga menyebabkan pengurus PGRI mengalami kesulitan untuk mengetahui informasi tentang anggota PGRI dan jumlah iuran sebenarnya yang akan mereka dapatkan dari setiap sekolah. Selain itu, proses pembayaran iuran juga masih menggunakan cara yang manual, yaitu bendahara sekolah bertemu dan memberi langsung uang iuran tersebut kepada pengurus PGRI.

Berdasarkan permasalahan tersebut, perlu suatu sistem informasi monitoring data PGRI kecamatan Bengkalis berbasis website yang mempermudahkan pengurus PGRI untuk memperoleh informasi dan melakukan monitoring data anggota PGRI Kecamatan Bengkalis. Selain itu, informasi tersebut dapat memberikan kemudahan bagi pihak sekolah dalam proses pendataan anggota PGRI. Desain sistem ini dirancang menggunakan metode XP dan framework $C I$ yang dapat menghasilkan informasi jumlah dan identitas sekolah, jumlah dan identitas anggota PGRI, siapa saja anggota PGRI yang belum terdaftar sebagai anggota resmi PGRI, serta monitoring pembayaran iuran PGRI.

\section{Metode Penelitian}




\subsection{Lokasi dan Pengumpulan Data Penelitian}

Lokasi penelitian untuk melakukan implementasi sistem informasi monitoring data PGRI yaitu PGRI kecamatan Bengkalis yangmerupakan salah satu Organisasi Guru di Provinsi Riau, bertepatan di Sekretariat PGRI, Jl. Antara Kecamatan Bengkalis. Untuk data didapatkan melalui proses wawacara kepada bagian yang terlibat dalam sistem, selain itu, metode Observasi juga dilakukan untuk memastikan data sesuai kebutuhan pengguna.

\subsection{Desain Penelitian}

Untuk melakukan desain sistem informasi monitoring data PGRI peneliti menggunakan metode $X P$, sedangkan bahasa yang digunakan adalah PHP dengan $C I$. Adapun tahapan metode $X P$ terdiri dari 4 (empat) tahapan yaitu:

1) Planning (Perencanaan)

Tahapan ini dimulai dengan melakukan identifikasi kebutuhan aktifitas suatu sistem yang terkait dengan data PGRI, melalukan analisa sistem yang sedang berjalan (Existing System) dan alur sistem yang baru (New System) untuk kebutuhan sistem yang akan dibangun.

2) Design (Perancangan)

Tahapan design merupakan langkah untuk pembuatan pemodelan sistem monitoring data PGRI berdasarkan hasil analisa kebutuhan yang telah didapatkan. Pemodelan sistem yang dilakukan yaitu menggunakan UML (Unified Modelling Language), yang terdiri dari Usecase dan Activity Diagram.Selain itu, pada tahapan ini juga melakukan pembuatan pemodelan basis data (Database) untuk menggambarkan hubungan antar data. Untuk pemodelan basis data menggunakan ERD (EntityRelationship Diagram) .

3) Coding (Pengkodean)

Tahapan coding merupakan langkah implementasi dari perancangan model yang telah dibuat sebelumnya kedalam sebuah kode program. Pada sistem monitoring data PGRI menggunakan bahasa pemrograman PHP dengan framework codeigniter, dan database yang digunakan yaitu MySQL.

4) Testing (Pengujian)

Tahapan pengujian merupakan langkah terakhir dari sistem informasi monitoring data PGRI, yang dimana merupakan tahap pengujian untuk mengetahui sistem yang dibangun apakah dapat berjalan sesuai dengan kebutuhan pengguna. Pengujian dilakukan dengan menggunakan metode blackboxtesting.[10][11]

Sedangkan bahasa yang digunakan dalam membagun sistem informasi monitoring data PGRI menggunakan $C I$ yang terdiri dari 3 (tiga) tahapan yaitu :

1) Model

Pada alur model merupakan program yang berupa OOP Class digunakan untuk memanipulasi data (Create, Read, Update, Delete) yang berhubungan dengan database MySql, menangani validasi pada bagian Controller, namun Model tidak dapat berhubungan langsung dengan View.

2) View

Pada alur view berisi tentang kode program berupa template yang digunakan untuk menampilkan data pada web browser. View atau tampilan biasanya berisi tag-tag HTML, CSS, dan Javascript yang berhubungan dengan penyajian data kepada user dan juga output variabel yang dikirimkan oleh Controller.

3) Controller

Controller merupakan kode program yang bisa dikatakan sebagai otak dari sebuah sistem, berupa OOP class yang digunakan sebagai pengontrol atau yang mengatur hubungan antara bagian model dan view.Selain itu juga memuat library utama, helper, dan setiap resource lainnya yang diperlukan untk memproses permintaan khusus.[12]

\section{Hasil dan Pembahasan}


Berdasarkan kondisi sistem saat ini masih menggunakan microsoft excell dalam melakukan proses input data guru yang bergabung sebagai anggota PGRI, proses monitoring iuran, monitoring jumlah data anggota, semua data di print out oleh operator sekolah untuk kebutuhan laporan di PGRI. Selain itu, pembahasan tentang sistem informasi data guru juga pernah dilakukan pada dinas pendidikan kota lubuklinggau menggunakan model UML dengan permasalahan tentang bagaimana melakukan proses pencarian, menyeleksi, dan menemukan guru atau tenaga pendidik menggunakan filter berdasarkan berdasarkan kecamatan, sekolah, jenjang pendidikan, pangkat guru, status pegawai, tingkat pendidikan yang diajarkan dan jenis kelamin serta golongan guru [14]. Berdasarkan masalah tersebut perlu dibuat sebuah sistem informasi monitoring data PGRI Kecamatan Bengkalis menggunakan bahasa pemograman PHP dan database MySQL untuk membantu pengelola PGRI, guru, tendik, dan operator sekolah dalam melihat data anggota PGRI yang ada di Kecamatan Bengkalis, seperti melihat identitas anggota (biodata, riwayat pendidikan, riwayat pekerjaan), melihat identitas sekolah, melakukan monitoring data guru berdasarkan sekolah, mengetahui siapa saja anggota yang belum terdaftar sebagai anggota resmi PGRI, monitoring pembayaran iuran, dan melihat bukti upload pembayaran iuran dari masing-masing sekolah.

Hasil penelitian ini berupa sebuah sistem informasi monitoring pendataan PGRI berbasis web menggunakan metode $X P$ dan $C I$ yang dapat memudahkan pengurus PGRI Kecamatan Bengkalis untuk mengetahui informasi yang terkait dengan anggota PGRI, serta melakukan monitoring data anggota PGRI Kecamatan Bengkalis. Adapun monitoring data yang dilakukan yaitu mengetahui jumlah dan identitas anggota PGRI, siapa saja anggota PGRI yang belum terdaftar sebagai anggota resmi PGRI, monitoring pembayaran iuran PGRI, dan melakukan monitoring jumlah sekolah serta identitas sekolah yang ada di Kecamatan Bengkalis. Berikut pembahasan mengenai tahapan $X P$ sebagai berikut:

1) Tahap Planning

Menjelaskan tentang sistem sistem informasi monitoring data PGRI dengan melibatkan beberapa user yaitu:

a. User admin; dapat mengelola sistem informasi monitoring data PGRI Kecamatan Bengkalis secara keseluruhan, baik itu proses input, update, delete, melihat data, dan melakukan approve registrasi Operator.

b. User Operator; dapat melakukan registrasi, login, update data sekolah, CRUD data pribadi, CRUD data anggota PGRI (Guru dan Tenaga kependidikan), serta melakukan upload bukti pembayaran iuran PGRI. Selain itu Operator juga diberi hak akses untuk melakukan Registrasi anggota PGRI di Sekolahnya apabila ada Guru dan Tenaga Kependidikan yang tidak bisa melakukan registrasi, dan juga bisa melakukan CRUD data Guru dan juga Tenaga kependidikannya.

c. User Guru dan Tenaga Kependidikan;dapat melakukan registrasi, login, CRUD data pribadi, seperti identitas diri, riwayat pendidikan dan riwayat pekerjaan.

Untuk lebih jelas tentang alur sistem yang diusulkan dapat dilihat pada gambar 1 .

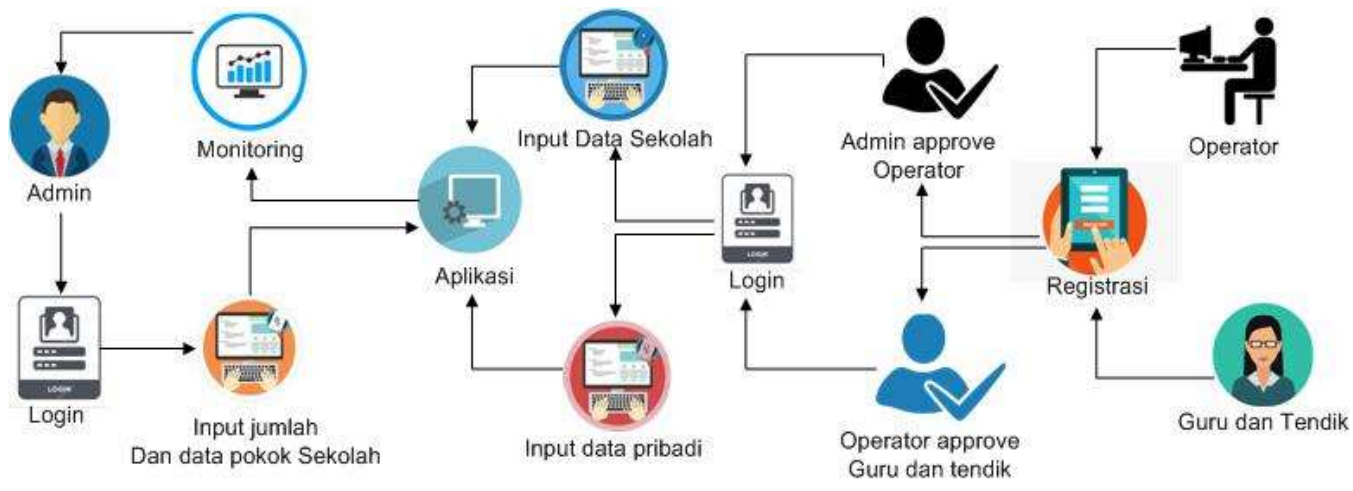

Gambar 1. Alur Sistem Informasi Monitoring Data PGRI(New System)

2) Tahap Design (Perancangan) 
Desain sistem menggunakan UMLuntuk membuat usecasediagram danactivity diagram, sedangkan untuk database menggunakan ERD (Entity Relationship Diagram) dan LRS (Logical Relationship Structure), untuk lebih jelas dapat dilihat sebagai berikut:

a. Usecase Diagram

Usecasediagram sistem informasi monitoring data PGRI merupakan gambaran terhadap aksi yang dilakukan pengguna kepada sistem[13]. Adapun pengguna sistem yang terlibat yaitu admin, operator, guru dan tenaga kependidikan, hal ini dapat dilihat pada Gambar 2.

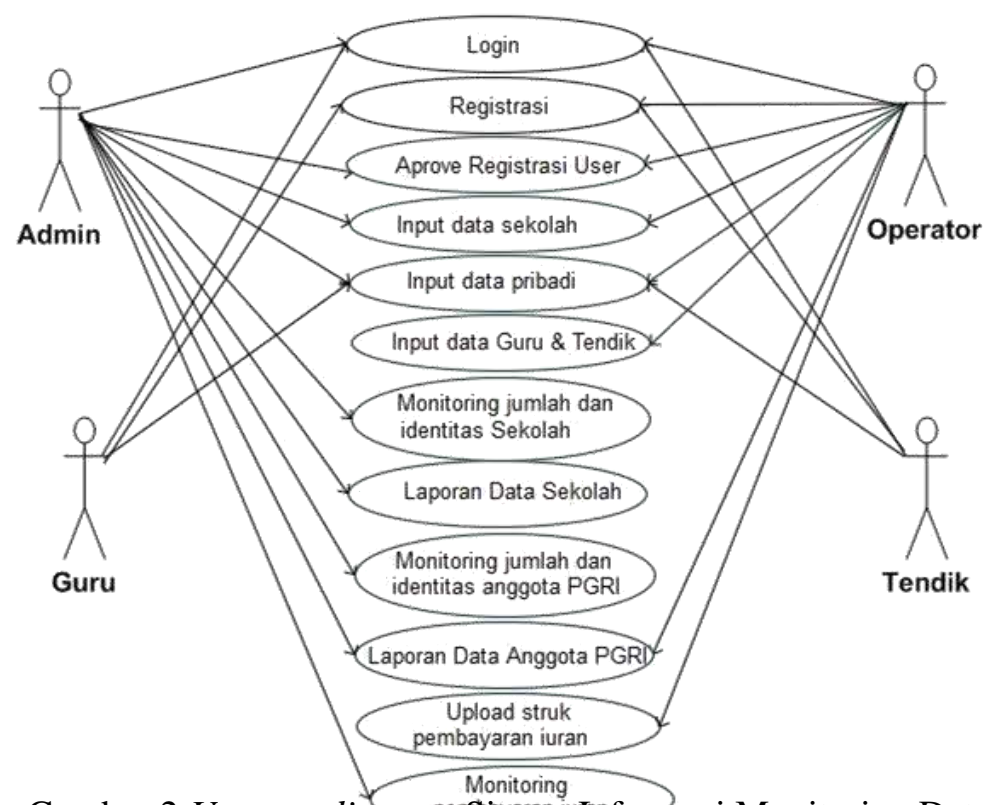

Gambar 2.Usecase diagrant Sistentu finformasi Monitoring Data PGRI

b. Activity Diagram

Menjelaskan tentang aktifitas yang dilakukan oleh para aktor yang terlibat dalam sistem informasi tersebut [14], dapat dilihat pada gambar berikut :

1. Activity diagram untuk monitoring jumlah sekolah dan identitas Sekolah

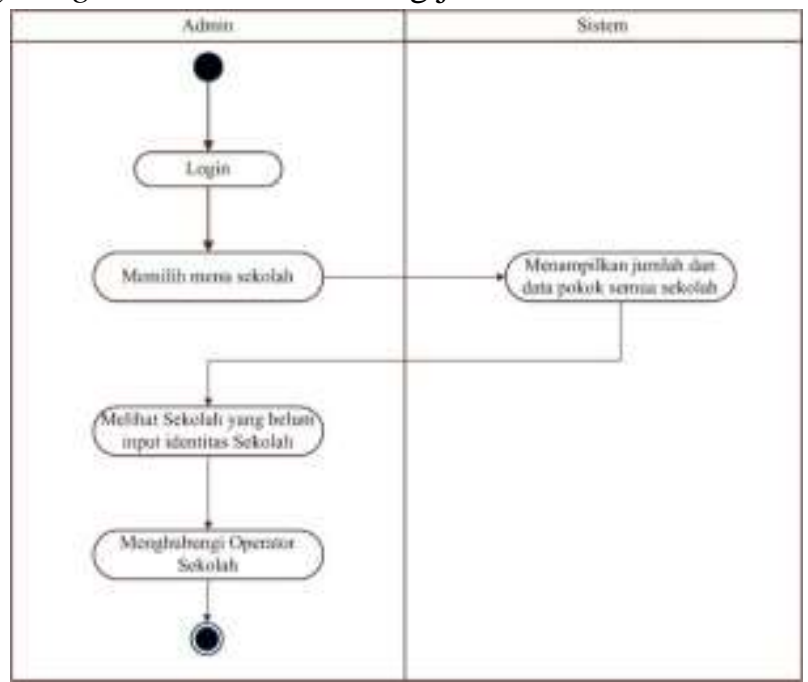

Gambar 3.Activity diagram untuk monitoring jumlah sekolah dan identitas Sekolah

2. Activity diagram untuk monitoring jumlah dan identitas anggota PGRI 


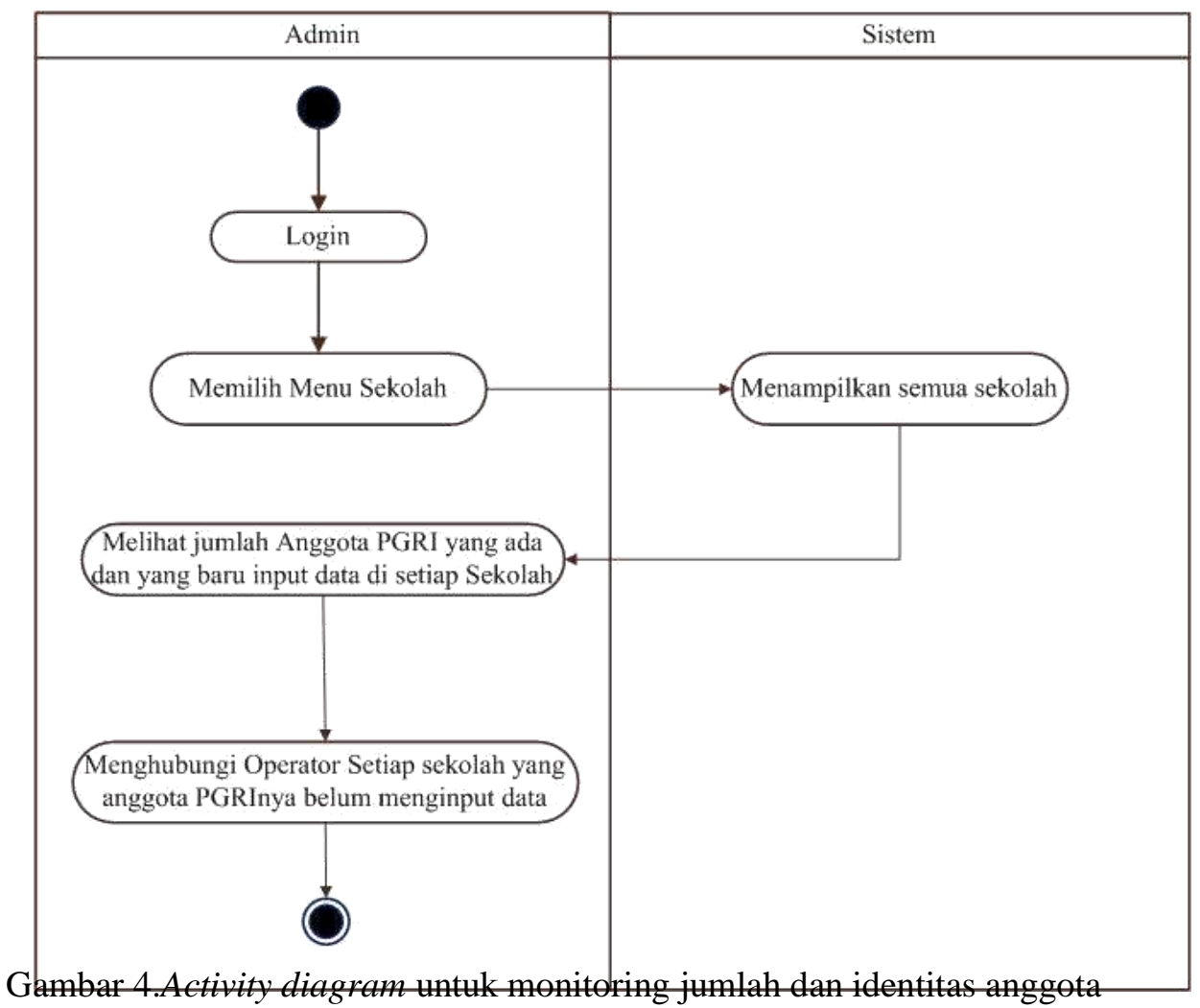

\section{PGRI}

3. Activity diagram untuk monitoring pembayaran iuran PGRI

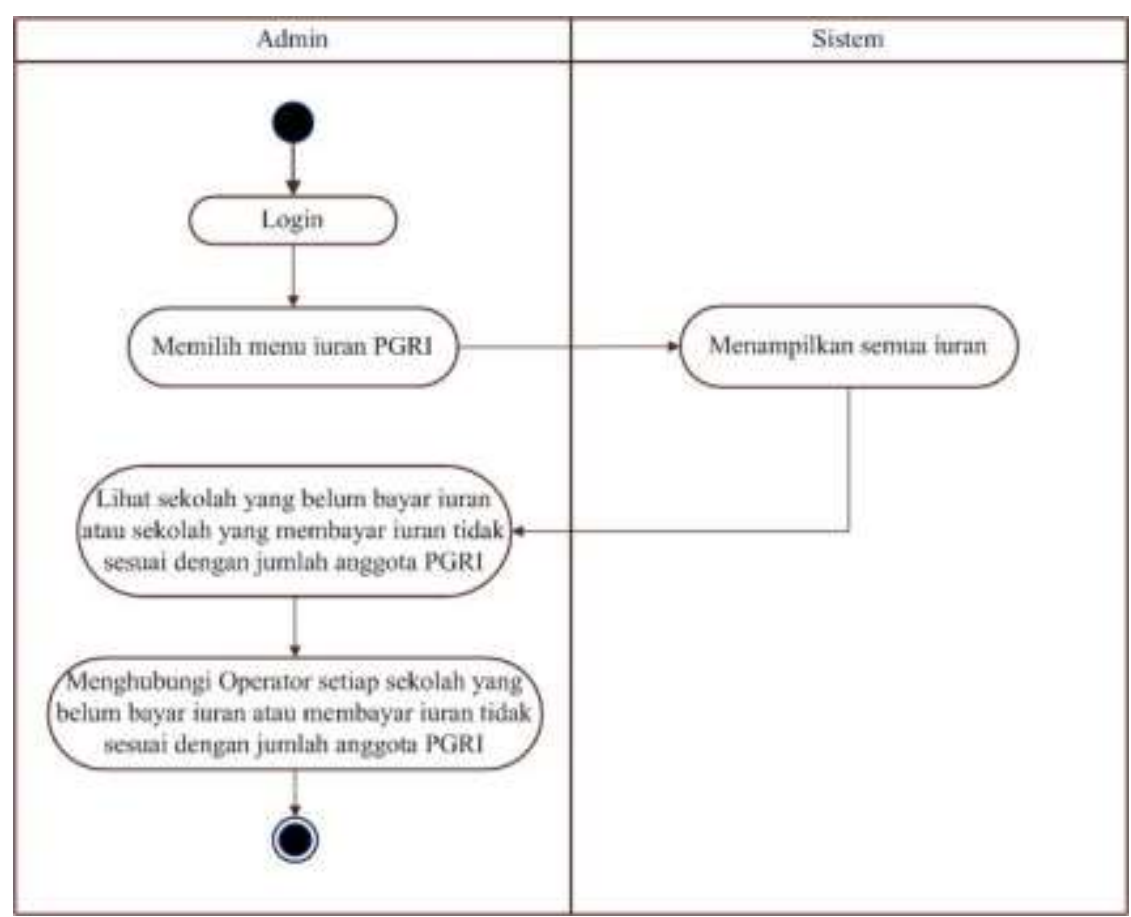

Gambar 5.Activity diagram untuk monitoring pembayaran iuran PGRI c. SequenceDiagram 
Gambar 6 menjelaskan tentang sequence diagram monitoring jumlah sekolah dan identitas Sekolah.

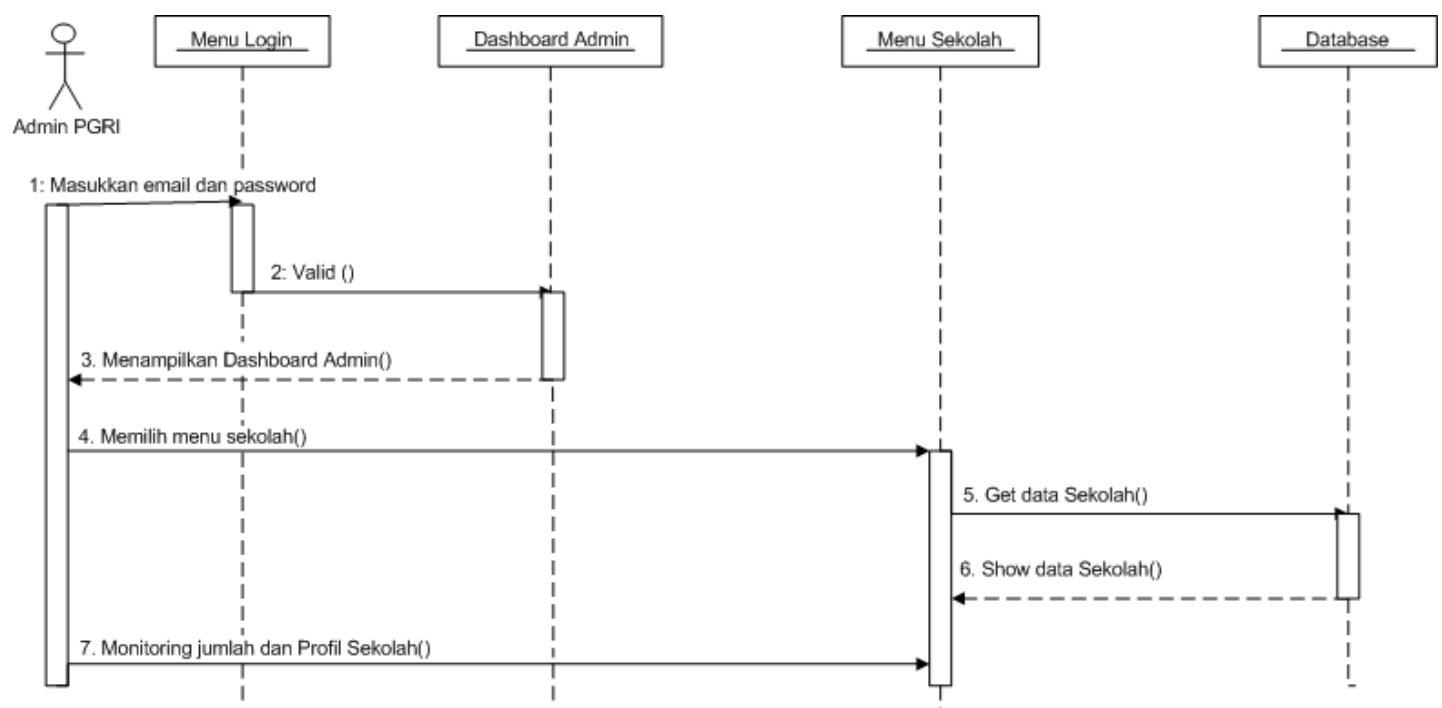

Gambar 6. Sequence Diagram monitoring jumlah Sekolah dan identitas Sekolah

Sedangkan Gambar 7 menjelaskan tentang monitoring jumlah dan identitas anggota PGRI

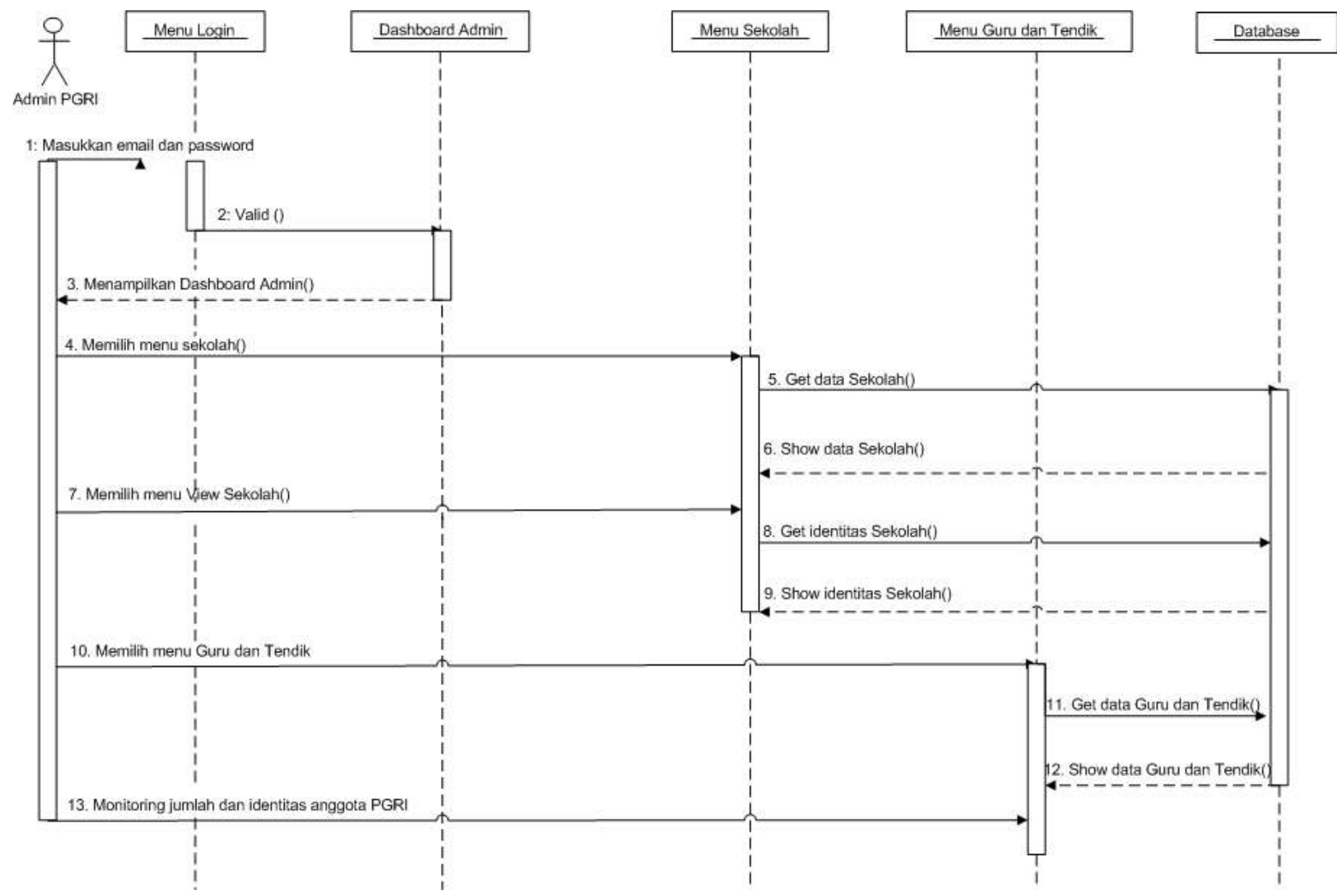

Gambar 7. Sequence Diagram monitoring jumlah dan identitas anggota PGRI

Sedangkan Gambar 8 menjelaskan sequence diagram tentang monitoring pembayaran iuran PGRI 


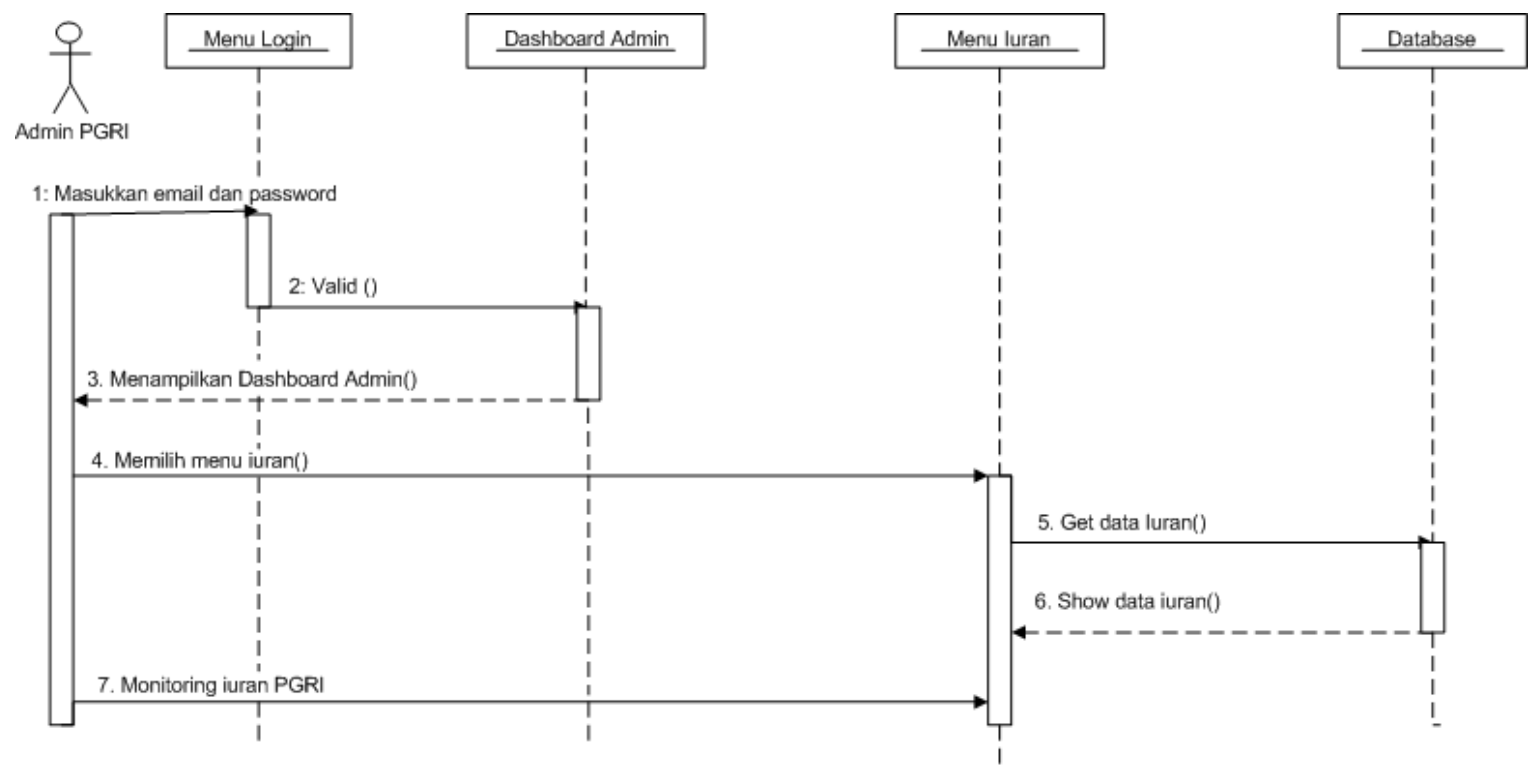

Gambar 8. Sequence Diagram monitoring pembayaran iuran PGRI

\section{d. ERD (Entity Relationship Diagram)}

Desain database sistem informasi monitoring data PGRI Kecamatan Bengkalis dapat dilihat pada Gambar 9.

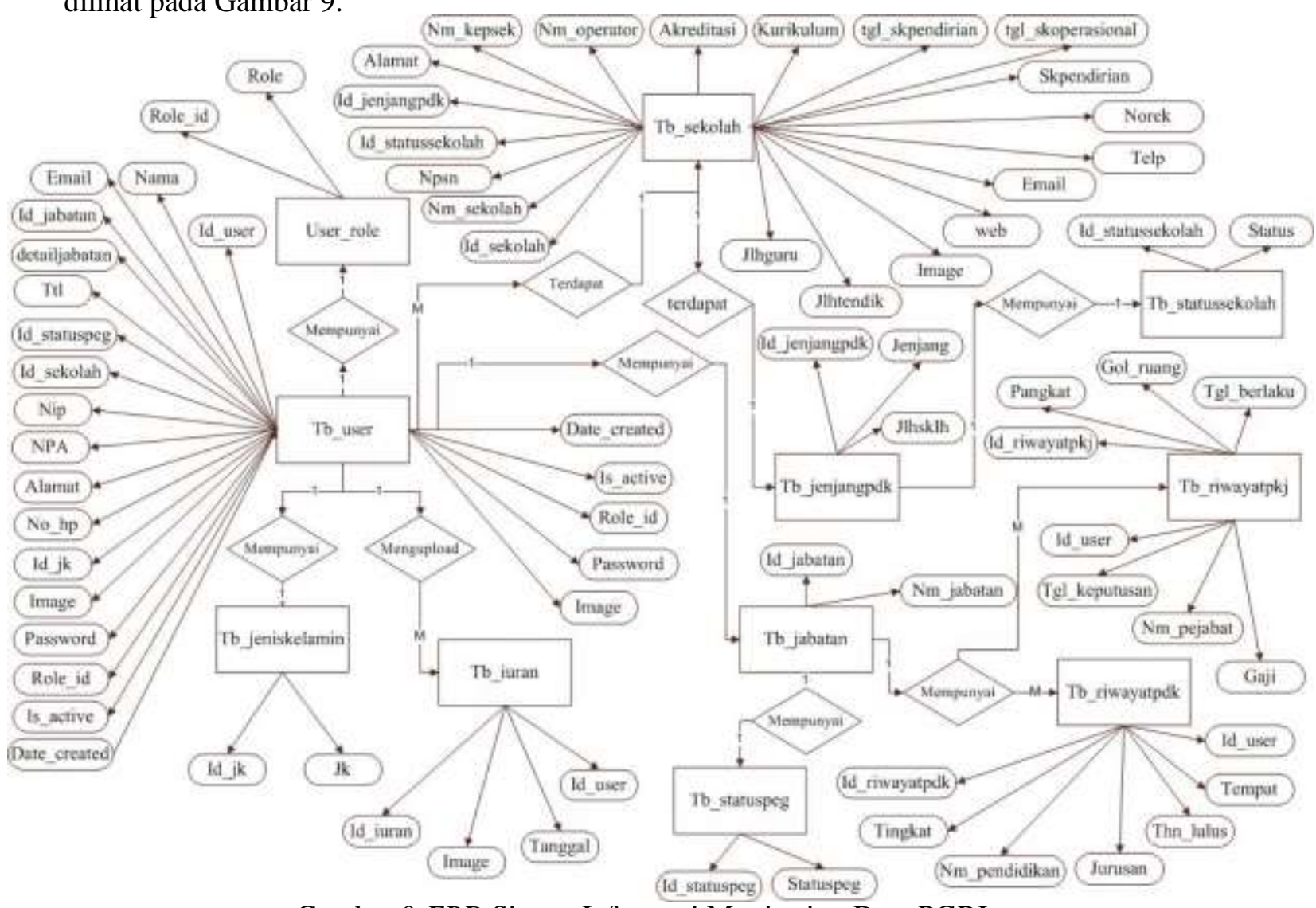

Gambar 9.ERD Sistem Informasi Monitoring Data PGRI

d. LRS (Logical Relationship Structure) 
Gambar 10 menjelaskan tentang bentuk Logical Relationship Structuredari database sistem informasi monitoring data PGRI.

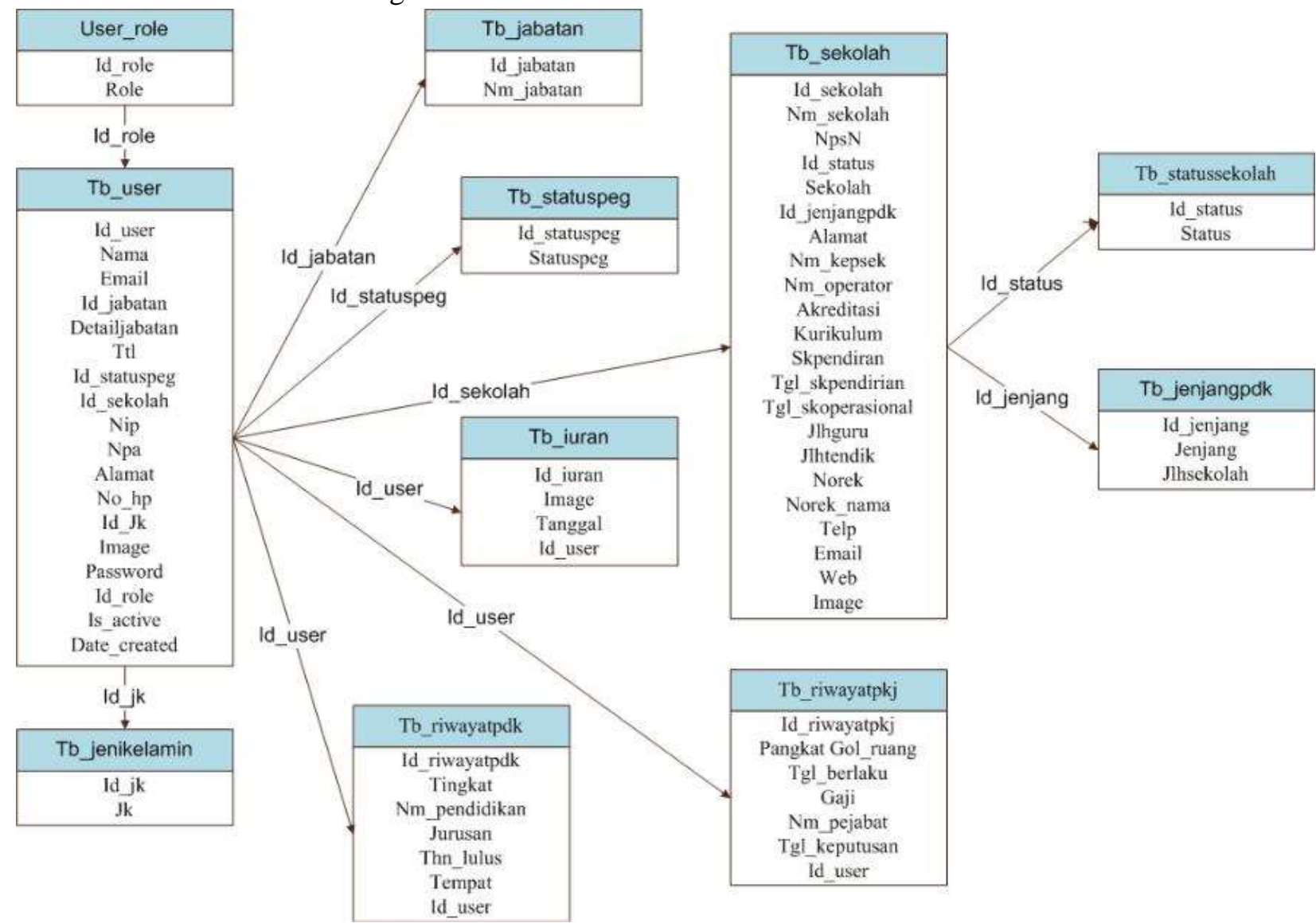

Gambar 10. LRS Sistem Informasi Monitoring Data PGRI

d. User Interface

Gambar 11menjelaskan tentang form logindimana admin, operator, dan guru dapat login sesuai dengan hak akses. Sedangkan form registrasi dapat digunakan untukoperator, guru dan tendik yang ingin membuat akun untuk masuk kedalam Aplikasi.
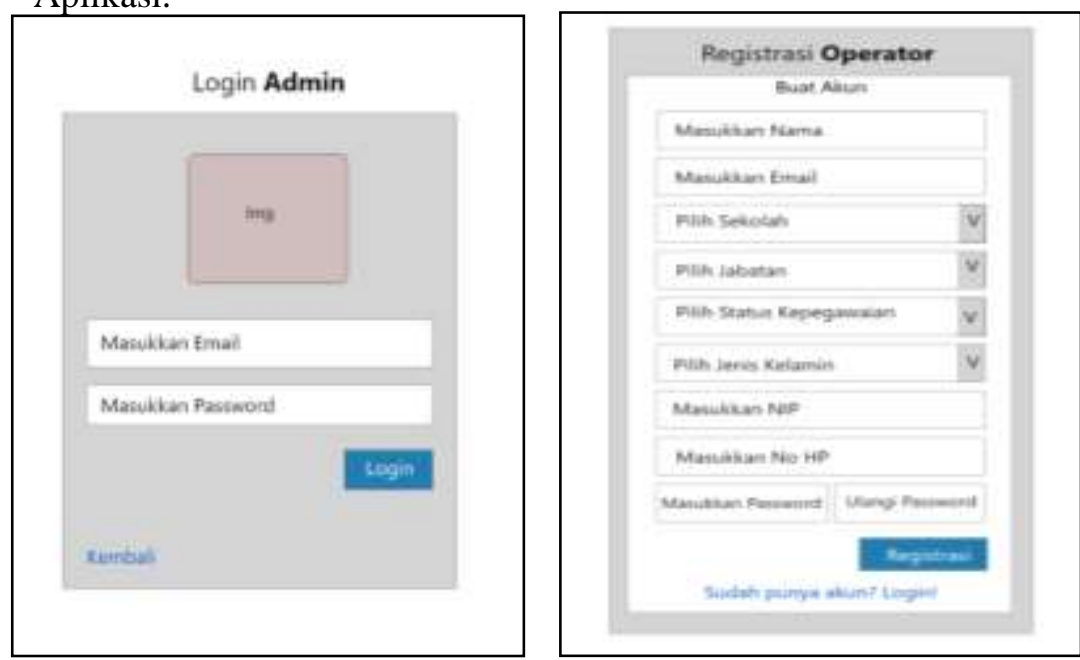

Gambar 11.Form Login dan Registrasi Sistem Informasi Monitoring Data PGRI 
Gambar 12 menjelaskan tentang form monitoring jumlah dan identitas sekolah dalam hal monitoring jumlahsekolah, admin dapat melihat keterangan yang ada pada bagian atas form(jumlah semua sekolah)yang berarti jumlah sekolah yang sebenarnya, dan jumlah sekolah belum inputberarti jumlah sekolah yang belum ditambahkan oleh admin kedalam sistem. Admin juga dapat melihat keterangan data yang sudah dimasukkan, form tersebut dapat dilihat dibawah ini.

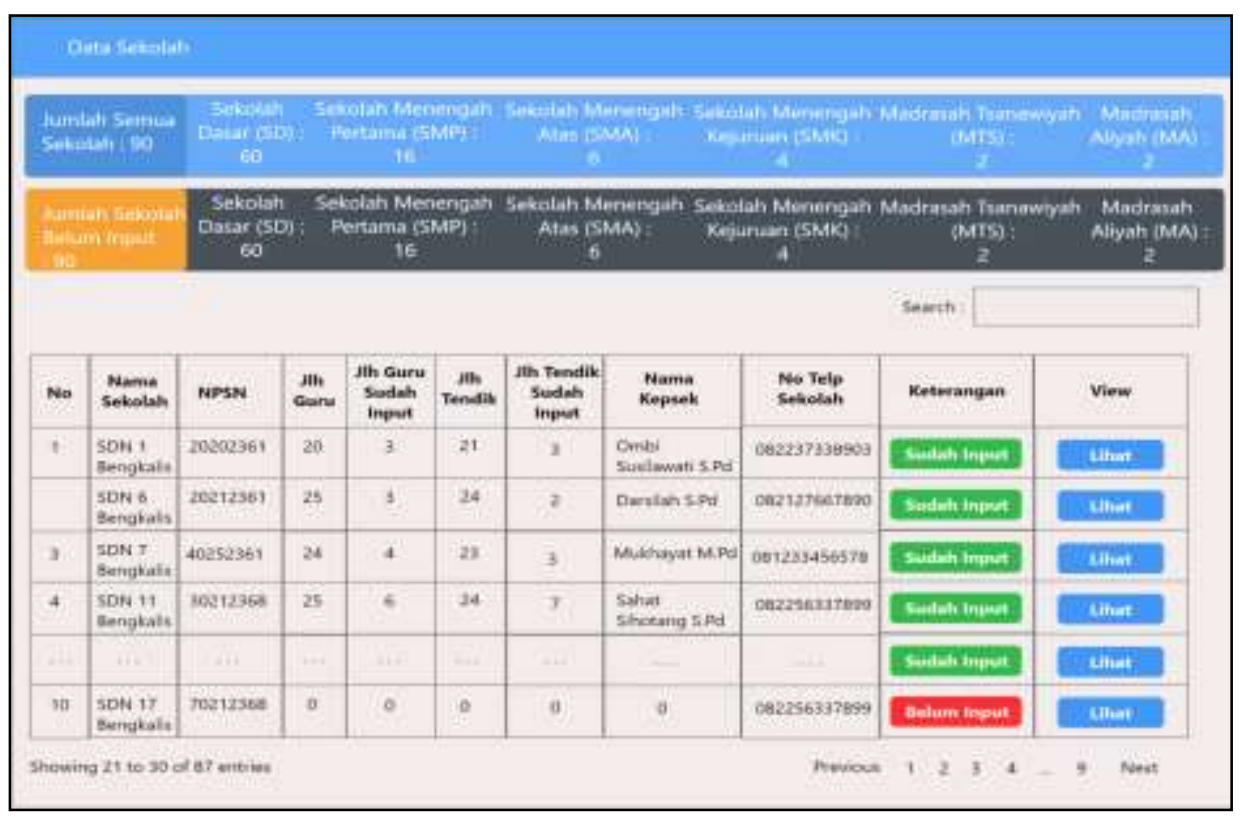

Gambar 12.Form Monitoring Jumlah dan Identitas SekolahSistem Informasi Monitoring Data PGRI

Gambar 13. menjelaskan tentang monitoring jumlah dan identitas anggota PGRI (Guru dan Tendik). Untuk melakukan hal tersebut admin dapat melihat tabel yang terdapat pada form yang ada keterangan jumlah guru, dan jumlah guru sudah input datapada sistem.

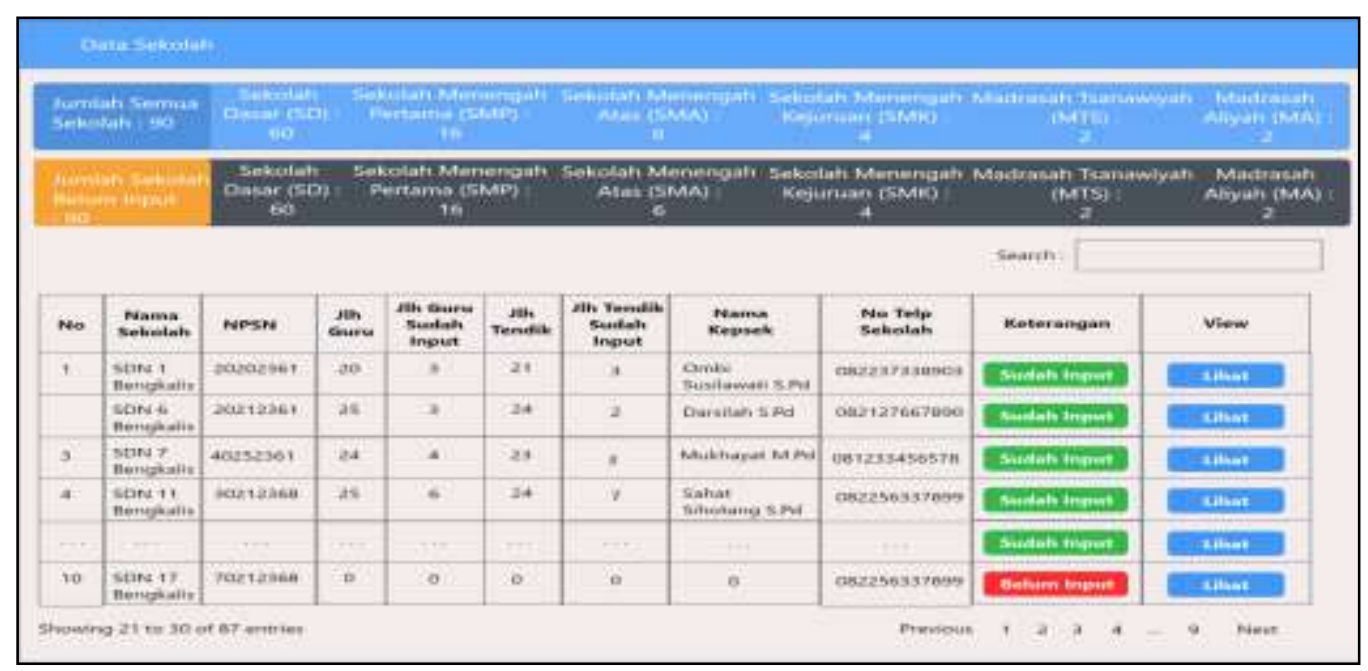

Gambar 13.Form Monitoring Jumlah dan Identitas anggota PGRI

Gambar 14 menjelaskan form monitoring pembayaran iuran PGRI. Monitoring dilakukan dengan cara melihat sekolah yang belum melakukan proses pembayaran berdasarkan bulan dan tahun. Apabila sekolah yang belum membayar maka admin dapat melihat pada table yang sudah disediakan.Selain itu, admin juga bisa mengetahui sekolah mana yang membayar 
iuran tidak sesuai dengan iuran semestinya, dengan cara membandingkan total iuran dan nominal yang telah ditransfer oleh pihak sekolah.

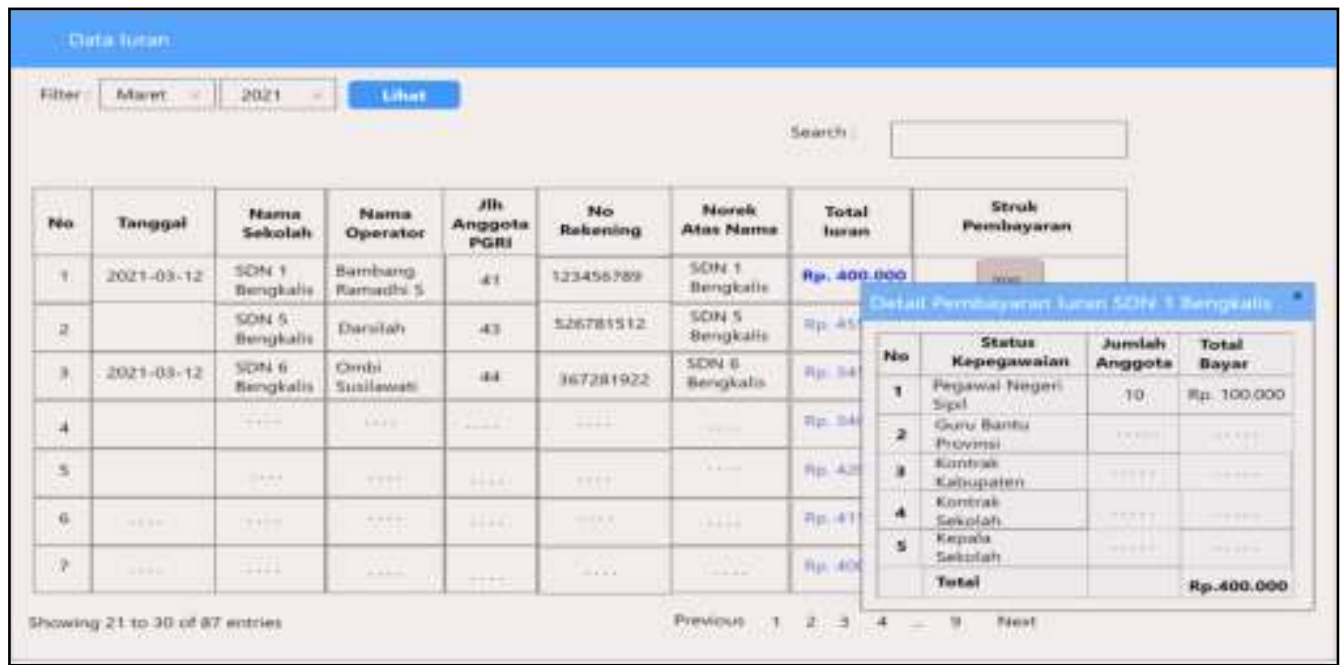

Gambar 14.Form Monitoring Pembayaran Iuran PGRI

\section{2) Tahap Testing}

Tahap testing merupakan langkah akhir untuk mengetahui tingkat keberhasilan pada sistem informasi monitoring data PGRI, untuk lebih jelas dapat dilihat pada Tabel 1.

Tabel I. Pengujian Form User (Admin, Operator, Guru dan Tendik)

\begin{tabular}{|c|c|c|c|}
\hline $\begin{array}{c}\text { Skema } \\
\text { Pengujian }\end{array}$ & $\begin{array}{l}\text { Teste } \\
\text { Case }\end{array}$ & Hasil Yang Diharapkan & $\begin{array}{c}\text { Hasil } \\
\text { Pengujian }\end{array}$ \\
\hline $\begin{array}{l}\text { Pengujian pada } \\
\text { form registrasi. }\end{array}$ & $\begin{array}{lr}\text { Guru dan } & \text { Tenaga } \\
\text { kependidikan } & \\
\text { menginput } & \text { data } \\
\text { pribadi. } & \end{array}$ & $\begin{array}{l}\text { Biodata berhasil tampil } \\
\text { kedalam form approval. }\end{array}$ & $\begin{array}{ll}\text { Aplikasi } & \text { berhasil } \\
\text { mengambil data } & \text { anggota } \\
\text { PGRI untuk proses } \\
\text { selanjutnya. }\end{array}$ \\
\hline $\begin{array}{l}\text { Pengujian pada } \\
\text { form Approve } \\
\text { disisi Admin } \\
\text { dan Operator }\end{array}$ & $\begin{array}{lr}\text { Admin dan } & \text { Operator } \\
\text { menyetujui } & \text { dan } \\
\text { menolak registrasi } \\
\text { user. }\end{array}$ & $\begin{array}{l}\text { User berhasil } \\
\text { ditambahkan apabila } \\
\text { registrasi diapprove oleh } \\
\text { Admin atau Operator. } \\
\text { Dan data user akan } \\
\text { terhapus apabila di } \\
\text { decline oleh Admin atau } \\
\text { Operator. }\end{array}$ & $\begin{array}{l}\text { Aplikasi } \\
\text { mengubah status } \\
\text { menjadi aktif, } \\
\text { mengubah level } \text { user. }\end{array}$ \\
\hline $\begin{array}{l}\text { Pengujian pada } \\
\text { form login. }\end{array}$ & $\begin{array}{lr}\text { Guru dan } & \text { Tenaga } \\
\text { Kependidikan } & \text { dapat } \\
\text { melakukan } & \text { login } \\
\text { apabilar registrasi } \\
\text { sudah disetujui. }\end{array}$ & $\begin{array}{l}\text { Aplikasi dapat membaca } \\
\text { serta mencocokkan email } \\
\text { dan password yang } \\
\text { sudah di approve. }\end{array}$ & $\begin{array}{l}\text { Login berhasil apabila } \\
\text { email dan password yang } \\
\text { dimasukkan sudah } \\
\text { terdaftar, jika email and } \\
\text { password yang } \\
\text { dimasukkan salah, akan } \\
\text { menampilkan pesan error }\end{array}$ \\
\hline $\begin{array}{lr}\text { Pengujian } & \text { pada } \\
\text { data } & \text { pokok } \\
\text { Sekolah } & \text { dan } \\
\text { Jenjang } & \end{array}$ & $\begin{array}{l}\text { Admin } \\
\text { menambahkan data, } \\
\text { dan mengisi jumlah } \\
\text { sekolah }\end{array}$ & $\begin{array}{lrr}\text { Admin } & \text { dapat } \\
\text { menambahkan } & \text { data } \\
\text { pokok sekolah } & \text { dan } \\
\text { jenjang } & \text { pendidikan }\end{array}$ & $\begin{array}{l}\text { Data sekolah dan jenjang } \\
\text { pendiikan yang ditambah } \\
\text { berhasil ditampilkan } \\
\text { kedalam Aplikasi. }\end{array}$ \\
\hline
\end{tabular}




\begin{tabular}{|c|c|c|c|}
\hline pendidikan & $\begin{array}{l}\text { dengan } \\
\text { pendidikan. }\end{array}$ & $\begin{array}{l}\text { sesuai } \\
\text { pengguna. }\end{array}$ & \\
\hline $\begin{array}{c}\text { Skema } \\
\text { Pengujian }\end{array}$ & $\begin{array}{l}\text { Teste } \\
\text { Case }\end{array}$ & Hasil Yang Diharapkan & $\begin{array}{c}\text { Hasil } \\
\text { Pengujian }\end{array}$ \\
\hline $\begin{array}{l}\text { Pengujian pada } \\
\text { identitas } \\
\text { sekolah }\end{array}$ & $\begin{array}{l}\text { Operator dapat input } \\
\text { identitas } \\
\text { sekolah. }\end{array}$ & $\begin{array}{l}\text { Operator dapat } \\
\text { menginput data identitas } \\
\text { sekolah dengan benar. }\end{array}$ & $\begin{array}{l}\text { Data yang sudah di-input } \\
\text { berhasil masuk dan } \\
\text { ditampilkan } \\
\text { Aplikasi. }\end{array}$ \\
\hline $\begin{array}{l}\text { Pengujian } \\
\text { monitoring data } \\
\text { sekolah }\end{array}$ & $\begin{array}{l}\text { Admin dapat melihat } \\
\text { jumlah sekolah yang } \\
\text { sudah dan belum di } \\
\text { input. }\end{array}$ & $\begin{array}{l}\text { Admin dapat melakukan } \\
\text { monitoring sekolah mana } \\
\text { yang belum melengkapi } \\
\text { data sekolah. }\end{array}$ & $\begin{array}{l}\text { Data yang akan di } \\
\text { monitoring berhasil tampil } \\
\text { pada menu sekolah. }\end{array}$ \\
\hline $\begin{array}{l}\text { Pengujian input } \\
\text { identitas } \\
\text { anggota PGRI }\end{array}$ & $\begin{array}{l}\text { Anggota PGRI } \\
\text { melakukan CRUD } \\
\text { identitas pribadi. }\end{array}$ & $\begin{array}{l}\text { Dapat melakukan CRUD } \\
\text { biodata, riwayat } \\
\text { pendidikan } \\
\text { pekerjaan. }\end{array}$ & $\begin{array}{l}\text { Data yang sudah diinput } \\
\text { berhasil dan ditampilkan } \\
\text { kedalam Aplikasi. }\end{array}$ \\
\hline $\begin{array}{l}\text { Pengujian } \\
\text { monitoring data } \\
\text { Anggota PGRI }\end{array}$ & $\begin{array}{l}\text { Admin dapat melihat } \\
\text { data sekolah, jumlah } \\
\text { guru ada, jumlah } \\
\text { guru yang belum } \\
\text { melengkapi data. }\end{array}$ & $\begin{array}{l}\text { Admin dapat melakukan } \\
\text { monitoring sekolah mana } \\
\text { yang jumlah Anggota } \\
\text { PGRI tidak } r \text { sesuai } \\
\text { dengan jumlah } \\
\text { sebenarnya serta yang } \\
\text { belum melengkapi data. }\end{array}$ & $\begin{array}{l}\text { Data jumlah anggota } \\
\text { PGRI berhasil ditampilkan } \\
\text { di menu sekolah, dan } \\
\text { identitas PGRI berhasil } \\
\text { ditampilkan pada detail } \\
\text { Sekolah di menu Anggota } \\
\text { PGRI. }\end{array}$ \\
\hline $\begin{array}{l}\text { Pengujian } \\
\text { upload struk } \\
\text { pembayaran } \\
\text { iuran PGRI. }\end{array}$ & $\begin{array}{l}\text { Operator mengupload } \\
\text { struk pembayaran } \\
\text { PGRI. }\end{array}$ & $\begin{array}{l}\text { Struk pembayaran iuran } \\
\text { PGRI berhasil diupload } \\
\text { dan tampil di menu } \\
\text { iuran. }\end{array}$ & $\begin{array}{l}\text { Struk pembayaran iuran } \\
\text { berhasil diupload oleh } \\
\text { Operator. }\end{array}$ \\
\hline $\begin{array}{l}\text { Pengujian } \\
\text { monitoring } \\
\text { pembayaran }\end{array}$ & $\begin{array}{l}\text { Admin melihat data } \\
\text { iuran bulanan, total } \\
\text { iuran dengan nominal } \\
\text { iuran pada struk } \\
\text { pembayaran. }\end{array}$ & $\begin{array}{l}\text { Admin dapat melakukan } \\
\text { monitoring sekolah yang } \\
\text { belum membayar dan } \\
\text { kurang bayar sesuai } \\
\text { dengan total iuran yang } \\
\text { seharusnya. }\end{array}$ & $\begin{array}{l}\text { Data iuran berhasil } \\
\text { ditampilkan pada menu } \\
\text { iuran. }\end{array}$ \\
\hline
\end{tabular}

Berdasarkan hasil pengujian sistem informasi monitoring data PGRI, dapat disimpulkan bahwa sistem informasi tersebut dapat berjalan sesuai dengan fungsinya dan semua sistem dapat diterima oleh pengurus PGRI dengan alamat website (http://pgrikecbengkalis.oi.id) sehingga sistem informasi tersebut dapat digunakan sesuai kebutuhan.

\section{Kesimpulan}

Sistem informasi monitoring data PGRI Kecamatan Bengkalis menggunakan metode XP dan Framework CI memiliki beberapa fasilitas dalam mengelola dan memonitoring data sekolah dilingkungan PGRI Kecamatan Bengkalis seperti melihat data anggota PGRI yang ada di Kecamatan Bengkalis, melihat identitas anggota PGRI seperti biodata, riwayat pendidikan, riwayat pekerjaan, dan juga melihat identitas sekolah. Pengurus PGRI dapat melakukan monitoring jumlah sekolah, monitoring anggota PGRI disetiap sekolah, monitoring anggota PGRI yang belum terdaftar sebagai anggota resmi PGRI, serta monitoring pembayaran iuran PGRI Kecamatan Bengkalis. Kemudian operator dapat mengupload bukti pembayaran iuran bulanan, melakukan filter iuran, export data sekolah dan monitoring jumlah data anggota PGRI yang ada di sekolahnya. Selain itu, guru dan tenaga kependidikan dapat menginput data pribadi seperti biodata, riwayat pendidikan, dan riwayat pekerjaan. Dengan adanya sistem informasi monitoring tersebut dapat membantu pengurus PGRI untuk mengelola dan memonitoring 
jumlah anggota PGRI secara online melalui halaman web (http://pgrikecbengkalis.oi.id) yang berada di Kecamatan Bengkalis secara konkrit sesuai dengan data yang ada disetiap sekolah.

\section{Daftar Pustaka}

[1] A. Prasetiyo, F. M Wargadalem, A. N Dhita, "Dinamika Konflik Antara Persatuan Guru Republik Indonesia dan Partai Komunis Indonesia," Jurnal Pendidikan dan Sejarah, Vol. 16, No. 1, 1-16, 2020.

[2] A. Kosasih, "Perjuangan Organisasi Guru di Masa Revolusi Sejarah PGRI di Awal Pendiriannya,"Jurnal Sosio-E-Kons, Vol. 8 No. 2, 91-103, 2016.

[3] A. S. Akbar, "Rancang Bangun Sistem Informasi Administrasi Hotel Dengan Metode Extreme Programming", Jurnal Disprotek Vol 8 Nomor 2, 26-41, 2017.

[4] M. B. D. Nugroho, M. C. Saputra, D. Pramono, "Pengembangan Sistem Informasi Monitoring Pengadaan Barang Atau Jasa Berbasis Website Dengan Metode Rational Unified Process (RUP) (Studi Kasus : Unit Bisnis Jasa O \& M 2 Luar Jawa PT PJB Surabaya)," Jurnal Pengembangan Teknologi Informasi dan Ilmu Komputer Vol. 2, No. 12, 7173-7182,2018.

[5] L. Rahmayani, Haryanto "Rancang Bangun Aplikasi Monitoring Laporan Quality Control Dan Defective Produksi Sepatu Berbasis Web (Studi Pada Pt. Panarub Industry)," JUTIS, Vol. 6, No.2, 76-81, 2018.

[6] L. Sadath, K. Karim, S.Gill, "Extreme Programming Implementation in Academia for SoftwareEngineering Sustainability," Advances in Science and Engineering Technology InternationalConferences, Vol. 5, No. 2, 1-6, 2018.

[7] Mansur, R. Yani, Kasmawi, "Desain Sistem Aplikasi Les Privat Menggunakan Pendekatan Metode Extreme Programming," Jurnal Teknologi Informasi \& Komunikasi Digital Zone , V. 11, No. 1, 30-42, 2020.

[8] J. A. Landicho, “A Web-Based Geographical Project Monitoring And Information System For TheRoad and Highways," Journal of Electrical Systems and Informations Technologhy, Vol. 5, No. 18,252-261, 2016.

[9] I. Sofiani, A. I. Nurhidayat, " Rancang Bangun Aplikasi E-Marketplace Hasil Pertanian Berbasis Website Dengan Menggunakan Framework Codeigniter," Jurnal Manajemen Informatika. Vol. 10, No. 01, 25-32, 2019.

[10] A. Supriyatna, "Metode Extreme Programming Pada Pembangunan Web Aplikasi Seleksi Peserta Pelatihan Kerja," Jurnal Teknik Informatika, Vol. 11 No.1, 1-18, 2018.

[11] M. Z. Hamidi, S. E. Anjarwani, I. W. A. Arimbawa, "Rancang Bangun Sistem Informasi Praktik Kerja Lapangan Pada Program Studi Teknik Informatika Universitas Mataram Menggunakan Extreme Programming," J-COSINE, Vol. 1, No. 1, 11-17, 2017.

[12] M. Destiningrum, Q. J. Andrian, "Sistem Informasi Penjadwalan Dokter Berbasis Web Dengan Menggunakan Framework Codeigniter(Studi Kasus: Rumah Sakit Yukum Medical Centre)," JurnalTEKNOINFO, Vol. 11, No. 2, 30-37, 2017.

[13] E. R. Suswanto, F. Ramadhan, "Rancang Bangun Aplikasi Berbasis Web Perizinan Praktik Tenaga Kesehatan Menggunakan Framework Codeigniter Pada Dinas Kesehatan Kota Metro," JurnalTEKNO KOMPAK, Vol. 11, No. 2, 55-60, 2017..

[14] H. O. L Wijaya, "Perancangan Sistem Informasi Data Guru Pada Dinas Pendidikan Kota Lubuklinggau, “ JTI, 8(1), 34-40, 2016.

[15] M. S. Dzakwan, Sunardi, A. Yudhana, "Monitoring Data Pendidik Menggunakan Metode Web Engineering", Cybernetics Vol. 4, No. 01, 19-31, 2020.

[16] A. L. Perdana, "Pelaksanaan dan Monitoring Evaluasi (Monev) Terhadap Kinerja Guru di SMAN 16 Gowa", Hubisintek, 44-52, 2020.

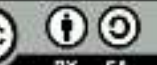

or \$n Digital Zone: Jurnal Teknologi Informasi dan Komunikasi is licensed under a Creative Commons Attribution International (CC BY-SA 4.0) 